\title{
Effects of Probiotic and Antibiotic Supplementation on some Blood Parameters in Collared Dove (Streptopelia decaocto)
}

\author{
Sinan Th. Abdullah \\ Department of Environmental Science/ College of Environmental Science and \\ Technology/University of Mosul \\ E-mail: sinantag@yahoo.com
}

(Received 22/1/2014;Accepted $10 / 3 / 2014$ )

\section{ABSTRACT}

This study is conducted to determine the normal blood parameter values in bird of Collared Dove (Streptopelia decaocto) and the effect of probiotic (Chunchine.Geyao ${ }^{\circledR}$ :China) and antibiotic (Tilmicosin phosphate-Tilmivap ${ }^{\circledR}$ :Jordan) on body weight, hematology and biochemical values in these birds. Forty apparently healthy adults of both sexes Collared dove were selected randomly and assigned into four equal groups $(\mathrm{n}=10)$ as $\mathrm{A}, \mathrm{B}, \mathrm{C}$ and $\mathrm{D}$ groups. Group A was considered as control group fed on a balanced ration, group B fed with the addition of $1.5 \mathrm{gm}$ probiotic/liter drinking water, group $\mathrm{C}$ fed with $0.3 \mathrm{ml}$ antibiotic/liter drinking water and group $\mathrm{D}$ were fed with $1.5 \mathrm{gm}$ probiotic and $0.3 \mathrm{ml}$ antibiotic/liter drinking water respectively during the 35 day of experimental period. The results showed that there is no significant differences in the heterophil, lymphocyte, heterophil/lymphocyte ratio, total serum cholesterol, ALT and in different treated groups. The present findings suggest that supplementation of Probiotic has significant effects on some hematology and biochemical parameters of Collared Dove (Streptopelia decaocto) compared to antibiotic supplementation.

Keywords: Probiotic, tilmicosin, body weight, hematology and biochemical parameters, Collared Dove (Streptopelia decaocto).

\section{تأثير إلفالة المعزز الحياتي والمضاد الحيوي فهض المعليير الموبة في الحمامة الفلختة}

\section{الملغص}

Collared اضضمت الدرلسة الحالية تحديد بعض المعايير الموية والكيميائية الحياتية الطبيعية في طائر الحملمة الفلختة (Chunchine.Geyao ${ }^{\circledR}$ China) ومدى تأثير المعلملة بالمعزز الحياتئية (Streptopelia decaocto) الحيوي (tilmicosin phosphate-Tilmivap ${ }^{\circledR}$ :Jordan) في كل من الزياة الوزنية للجمم والتغيرات الموية والكيميائية

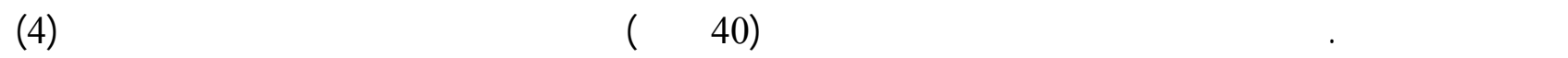
مجلمبع متساوية (0الطائر/معلملة). المجموعة الأوله عدت مجموعةسيطرة غنيت على العليقة المتوازنة، المجموعة الثانية

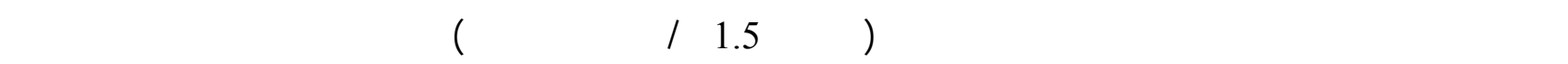

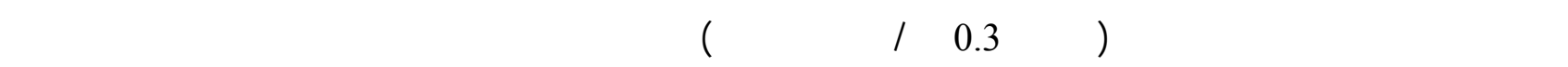

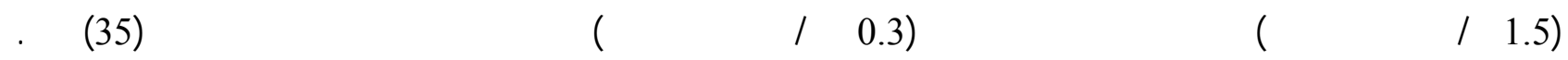

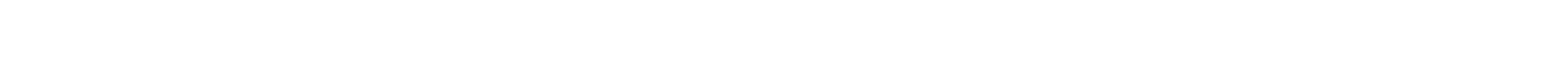
للسطرة، في حن كانت هنك فروق معنوية واضحة في معدلات قيم لكل من خلايا المم البيضاء (العدلة، واللففية، ونسبة العدلة

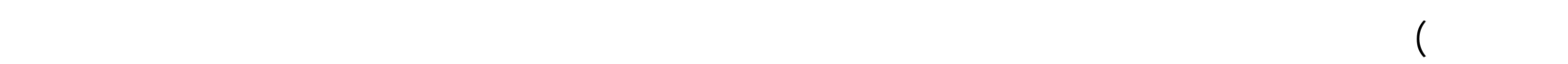

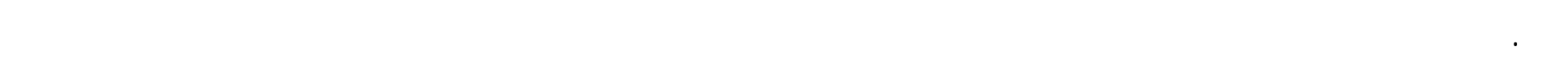
لستخدل المضاد الحيوي في نموذجطائر الحملمة الفلختة. 


\section{INTRODUCTION}

Although the Collared Dove is normally assigned its own systematic name, as (Streptopelia decaocto), (Allouse, 1962), considerable doubt exists as to its appropriate classification. It is one of the great colonizers of the avian world, (David et al., 2001). Its original range was warmer temperate regions from South Eastern Europe to Japan (Beckett et al., 2007). The values of hematological indices in domestic and wild birds could be an important source of information with valuable diagnostic meaning (Miller et al., 2001). They could provide or support an objective assessment of the health status and could support the correct diagnosis in different pathological states (Hauptmanova et al., 2002). This has motivated the publication of a large number of scientific reports in various free living or captured avian species (Palvak et al., 2005). At present there is no alternative but to use antibiotics to prevent the considerable loss to the domestic and wild birds due to various bacterial and other infections (Kamruzzaman et al., 2005). Antibiotics are the most widely used drugs in veterinary medicine, tilmicosine is a veterinary macrolide antibiotic which has been prepared by chemical modification of desmycosin. It has been used in therapy of different diseases in livestock and poultry (Modric et al., 1999). The possibility of antibiotics ceasing to be used as growth stimulants for farm animals and the concern about the side effects of their use as therapeutic agents has produced a climate in which both consumer and manufacturer are looking for alternatives (Kamruzzaman et al., 2005). Probiotics are being brought under consideration to fill this gap and already some farmers are using them in preference to antibiotics (Fuller, 1989). Liver function test is one of the most common blood tests. Abnormal results in the liver function test often cause considerable anxiety in asymptomatic subjects. It may lead more investigations to ascertain if there is underlying serious liver disease. The most common abnormalities of liver function test in an asymptomatic person is alanine aminotransferase (ALT) and aspartate aminotransferase (AST) (Giannini et al., 2005). In modern poultry, domestic and wild birds production, different types of growth promotes are used (Abd-El-Rahman et al., 2012). The public concern about resistant pathogenic bacteria in humans lead to increasing pressure by the consumer for a reduction or ban on the use of nutritive antibiotics (Awaad and Zouelfeker, 2001). Probiotics are new products which are live microbes grow in the gastrointestinal tract and create beneficial conditions for nutrients' utilization and inhibit the growth of pathogenic bacteria in the host (Amer and Khan, 2012). It has been reported recently that utilization of probiotics in animal nutrition is of economic and health benefits (Gardiner et al., 2004). The present study therefore was aimed to evaluate the effect of probiotics (Chunchine.Geyao ${ }^{\circledR}$ : China) and antibiotic (tilmicosin phosphate) on the performance and hematological and biochemical parameters of Collared Dove (Streptopelia decaocto).

\section{MATERIALS AND METHODS}

The birds used in the present study were apparently healthy adults of both sexes of Collared Dove (Streptopelia decaocto) were commonly obtained from a local market in Mosul, Iraq from October and November 2013 . The birds were individually kept in captivity cages $(80 \times 60 \times 70 \mathrm{~cm})$ of about $25 \mathrm{C}^{\mathrm{o}}$ with water and poultry feed available ad libitum for 7-14 days before experiments. All the experiments were complied with institutional regulations addressing animal use, and proper attention and care were given to the birds used in this study.

\section{Experimental design}

Collared Dove were randomly divided into four groups (10 birds per group) and fed for 35 days the following diets:

1. Group A (control): Diet contained essential nutrients optimal to the requirements of birds (NRC, 1984).

2. Group B: Probiotic (Chunchine.Geyao ${ }^{\circledR}$ : China) $1.5 \mathrm{gm} /$ liter drinking water.

3. Group C: Antibiotic (tilmicosin phosphate-Tilmivap ${ }^{\mathbb{B}}$ : Jordan) $0.3 \mathrm{ml} /$ litter drinking water.

4. Group D: Probiotic (Chunchine.Geyao ${ }^{\circledR}$ : China)1.5gm and Antibiotic (tilmicosin phosphateTilmivap $^{\circledR}$ : Jordan) $0.3 \mathrm{ml} /$ litter drinking water. 
The body weight of each bird of all the four groups was taken weekly during the 35 days of experimental period (Kamruzzaman et al., 2005).

\section{Sampling and analysis}

At the end of experiment (35) days the control and treated birds were euthanised by decapitation and blood samples were collected using heparin zed test tubes. The hematological studies were performed within two hours of blood collection. Total erythrocyte count (TEC), White blood cell count (WBC) were obtained with haemocytometer. The differential WBC counts were determined on the same blood smears, by counting $200 \mathrm{WBC}$ from a representative part of the smears.

Hemoglobin $(\mathrm{Hb})$ concentration $(\mathrm{g} / \mathrm{dl})$ and packed cell volume (PVC \%) were determined by sahli haemometer and microhaematocrit methods, respectively immediately before serum separation by blood centrifugation (Shanghai instruments factory 80-2 centrifuge, China) at $3000 \mathrm{cir} / \mathrm{min}$ for 15 minute.

Mean corpuscular volume (MCV), mean corpuscular hemoglobin $(\mathrm{MCH})$ and mean corpuscular hemoglobin concentration (MCHC) levels were calculated.

Serum biochemical (total cholesterol) analysis, estimation of Alanine Aminotransferase activity (ALT) and Aspatate Aminotransferase activity (AST) in the serum were performed by (Reflotron plus 2011, Roche, Germany) the instrument is work on the principle of reflectance photometry (Grunenberg et al., 1995).

\section{Statistical analysis}

Analysis of data was performed using analysis of variance ANOVA test by SPSS program (ver.12) to determine mean \pm S.E. Duncan's Multiple range test were used to determine significant difference between the groups at $\mathrm{P} \leq 0.05$ (Steel and Torrie,1980).

\section{RESULTS AND DISCUTION}

Effect of probiotic and antibiotic supplementation on body weight gain is present in (Table 1). The body weight gains corresponding to the different treatments did not differ significantly $(\mathrm{P} \leq 0.05)$ in all groups. The results obtained coincide with the finding of Ergun et al.,(2000) who stated that supplementation of probiotic, with or without antibiotic, to the rations has no important effect on live weight gain. In comply with Yeo and Kim, (1997) results, the body weight increases in birds only during the first 3 weeks but not during adult of age, but contradicted with Pradhan et al., (1998) and Islam et al., (2004), they stated that supplementation of probiotics can be increase significantly the weight gains.

Table 1: Effect of probiotic and antibiotic supplementation on body weight gain in Collared Dove (Streptopelia decaocto)

\begin{tabular}{|c|c|c|c|}
\hline \multicolumn{5}{|c|}{ Groups of birds * } \\
\hline (control) & $\begin{array}{c}\text { Probiotic 1.5gm /liter } \\
\text { drinking water }\end{array}$ & $\begin{array}{c}\text { Antibiotic } \\
\text { 0.3ml/litter drinking water }\end{array}$ & $\begin{array}{c}\text { Probiotic 1.5gm } \\
\text { and } \\
\text { antibiotic 0.3ml/litter } \\
\text { drinking water }\end{array}$ \\
\hline $\begin{array}{c}116.451 \mathrm{~g} \pm 18.80 \\
\mathrm{a}\end{array}$ & $\begin{array}{c}120.276 \mathrm{~g} \pm 6.63 \\
\mathrm{a}\end{array}$ & $\begin{array}{c}118.467 \mathrm{~g} \pm 51.09 \\
\mathrm{a}\end{array}$ & $\begin{array}{c}119.345 \mathrm{~g} \pm 43.18 \\
\mathrm{a}\end{array}$ \\
\hline
\end{tabular}

* Mean \pm S.E. for 10 birds in each group.

Similar letters mean un significant differences $\mathrm{P} \leq 0.05$.

The results of hematological parameters are summarized in (Table 2), it was obvious that probiotic and antibiotic has no significant effect on hematological parameters, this results agreed with Kander, (2004), which may due to that the Probiotic and antibiotic has no direct effects on hematological values, and the age 
was likely to be a factor affecting the blood forming process and this data suggested that as a birds grew up, the ability to synthesized hematological parameters also increased and became stable in adults (Kander, 2004). This results agreed with results of Mohan et al, (1996), who reported that the packed cell volume not varied with probiotic supplementation. The present contradicted results with Islam et al., (2004), who reported that the hematological parameters are increased significantly in Probiotic and antibiotic supplementation. It was obvious that the probiotics and antibiotics supplementation has no direct effects on $\mathrm{Hb}$ concentration, $\mathrm{PCV} \%, \mathrm{MCV}(\%), \mathrm{MCH}(\mathrm{pg})$ and $\mathrm{MCHC}(\%)$.

Table 2: Individual comparison of the mean values of certain hematological parameters corresponding to the treated groups with the mean of control group

\begin{tabular}{|c|c|c|c|c|}
\hline \multicolumn{5}{|c|}{ Groups of birds * } \\
\hline & Parameters & $\begin{array}{c}\text { Probiotic 1.5 gm } \\
\text { /liter drinking } \\
\text { water }\end{array}$ & $\begin{array}{c}\text { Antibiotic } \\
\text { 0.3ml/litter } \\
\text { drinking water }\end{array}$ & $\begin{array}{c}\text { Probiotic 1.5gm } \\
\text { and antibiotic } \\
\text { 0.3ml/litter } \\
\text { drinking water }\end{array}$ \\
\hline $\mathrm{TEC}\left(10^{12} / \mathrm{L}\right)$ & $4.31 \pm 0.09 \mathrm{a}$ & $4.62 \pm 0.03 \mathrm{a}$ & $4.49 \pm 0.09 \mathrm{a}$ & $4.59 \pm 0.27 \mathrm{a}$ \\
$\mathrm{Hb}(\mathrm{g} / \mathrm{dl})$ & $11.38 \pm 0.73 \mathrm{a}$ & $12.87 \pm 0.58 \mathrm{a}$ & $12.30 \pm 0.67 \mathrm{a}$ & $13.10 \pm 0.42 \mathrm{a}$ \\
$\mathrm{PCV}(\%)$ & $36.30 \pm 0.47 \mathrm{a}$ & $34.22 \pm 0.43 \mathrm{a}$ & $37.42 \pm 0.34 \mathrm{a}$ & $34.11 \pm 0.14 \mathrm{a}$ \\
$\mathrm{MCV}(\mathrm{fl})$ & $90.89 \pm 0.87 \mathrm{a}$ & $91.67 \pm 0.55 \mathrm{a}$ & $89.33 \pm 0.86 \mathrm{a}$ & $92.20 \pm 1.56 \mathrm{a}$ \\
$\mathrm{MCH}(\mathrm{pg})$ & $27.68 \pm 2.12 \mathrm{a}$ & $26.89 \pm 3.10 \mathrm{a}$ & $28.91 \pm 4.33 \mathrm{a}$ & $29.43 \pm 1.33 \mathrm{a}$ \\
$\mathrm{MCHC}(\%)$ & $31.34 \pm 1.57 \mathrm{a}$ & $29.56 \pm 4.59 \mathrm{a}$ & $28.08 \pm 1.45 \mathrm{a}$ & $30.37 \pm 2.14 \mathrm{a}$ \\
\hline
\end{tabular}

* Mean \pm S.E. for 10 birds in each group.

Similar letters mean un significant differences $\mathrm{P} \leq 0.05$.

From (Table 2) it is noted that there is no significant differences in total number of leukocytes, eosinophil (\%), basophil (\%) and monocyte (\%), but the percentage of heterophil, lymphocyte and $\mathrm{H} / \mathrm{L}$ ratio were increased in birds receiving both probiotic and antibiotic, the increase in H/L ratio may indicate the response to stress, (Table 3 ). It is readily accepted that the increase in heterophil, lymphocyte and $\mathrm{H} / \mathrm{L}$ ratio are indicators of stress in chickens and birds (Post et al., 2003).

Table 3: Individual comparison of the mean values of certain leukocyte parameters corresponding to the treated groups with the mean of control group.

\begin{tabular}{|c|c|c|c|c|}
\hline \multicolumn{5}{|c|}{ Groups of birds * } \\
\hline Parameters & (control) & $\begin{array}{c}\text { Probiotic } 1.5 \text { gm } \\
\text { /liter drinking } \\
\text { water }\end{array}$ & $\begin{array}{c}\text { Antibiotic } \\
0.3 \mathrm{ml} / \text { litter } \\
\text { drinking water }\end{array}$ & $\begin{array}{c}\text { Probiotic 1.5gm } \\
\text { and antibiotic } \\
0.3 \mathrm{ml} / \text { litter } \\
\text { drinking water }\end{array}$ \\
\hline $\begin{array}{l}\text { TLC }\left(10^{9} / \mathrm{L}\right) \\
\text { Heterophil(\%) } \\
\text { Eosinophil(\%) } \\
\text { Basophil(\%) } \\
\text { Lymphocyte(\%) } \\
\text { Monocyte(\%) } \\
\text { H/L ratio }\end{array}$ & $\begin{array}{l}22.56 \pm 0.57 \mathrm{a} \\
38.42 \pm 0.20 \mathrm{a} \\
1.87 \pm 0.53 \mathrm{a} \\
1.29 \pm 0.33 \mathrm{a} \\
49.93 \pm 0.14 \mathrm{a} \\
0.38 \pm 0.69 \mathrm{a} \\
0.77 \pm 0.40 \mathrm{a}\end{array}$ & $\begin{array}{l}23.69 \pm 1.70 \mathrm{a} \\
44.80 \pm 0.30 \mathrm{~b} \\
1.66 \pm 0.14 \mathrm{a} \\
1.32 \pm 0.53 \mathrm{a} \\
56.13 \pm 0.22 \mathrm{~b} \\
0.35 \pm 0.53 \mathrm{a} \\
0.85 \pm 0.79 \mathrm{~b}\end{array}$ & $\begin{array}{l}23.90 \pm 0.57 \mathrm{a} \\
43.33 \pm 0.38 \mathrm{~b} \\
1.72 \pm 0.36 \mathrm{a} \\
1.31 \pm 1.43 \mathrm{a} \\
56.36 \pm 0.51 \mathrm{~b} \\
0.61 \pm 0.19 \mathrm{a} \\
0.88 \pm 0.80 \mathrm{~b}\end{array}$ & $\begin{array}{l}22.89 \pm 0.95 \mathrm{a} \\
45.20 \pm 0.38 \mathrm{~b} \\
1.59 \pm 0.19 \mathrm{a} \\
1.30 \pm 0.39 \mathrm{a} \\
54.36 \pm 0.63 \mathrm{~b} \\
0.59 \pm 0.20 \mathrm{a} \\
0.87 \pm 0.27 \mathrm{~b}\end{array}$ \\
\hline
\end{tabular}

* Mean \pm S.E. for 10 birds in each group.

Similar letters mean un significant differences $\mathrm{P} \leq 0.05$. 
Cholesterol levels in avian blood are affected by age, heredity, nutrition and various diseases (Thongsong et al., 2008). (Table 4) shows that serum cholesterol level was significantly $(\mathrm{P} \leq 0.05)$ lower in birds receiving diets containing probiotics, this results were in agreement with (Panda et al., 2006), (Murwani and Bayuardhi, 2007). Additionally, Kalvathy et al., (2006) as well reported that the cholesterol in the livers and carcasses of broilers was also lower in birds fed with diets containing lactobacillus. The differences between the results of this study and others could be due to the difference in strain/species of probiotic microorganism used or the rout of administration. Moreover, the age of birds also played a part in the level of cholesterol, it may be that cholesterol is required during growing period for the development of muscle and tissue (Thongsong et al., 2008). In order to assess the potential health benefits to consumers of cholesterol levels in birds, the results of this work indicates that the birds supplemented with antibiotic (tilmicosin phosphate) has a significant increase in serum cholesterol levels. Our result (Table 4) agreed with the Murwani and Bayuardhi, (2007), who suggested that antibiotic in feed and the medication programs of broilers can affect the lipid and hepatic metabolism of broilers and be reflect by an increase in serum cholesterol.

Serum aminotransferase (ALT and AST) values were significantly decreased in all three groups in comparing with control group (Table 4). This result agree with Mathivanan and Kalaiorasi, (2007), who demonstrated that ALT and AST were differ significantly in birds treated with probiotic and antibiotic. This result may be due to the beneficial effect of probiotic on the hepatic cells leading to decrease in serum ALT and AST (Mathivanan and Kalaiorasi, 2007). The decreasing effects of antibiotic to ALT and AST in this study may be caused by a lower enzyme activity (Nikpiran et al., 2013). But this study finding is disagree with Islam et al., (2004) who find that ALT and AST not significantly affected by probiotic and antibiotic treatments.

From the present study, appeared that there was no effects of probiotics and antibiotics in growth performance of Collared Dove (Streptopelia decaocto), and suggest that supplementation of probiotic and antibiotic has significant influences on hematology and biochemical parameters in Collared Dove (Streptopelia decaocto).

Table 4: Values of serum total cholesterol, ALT and AST in Collared Dove (Streptopelia decaocto)

\begin{tabular}{|c|c|c|c|c|}
\hline \multicolumn{5}{|c|}{ Groups of birds * } \\
\hline Parameters & (control) & $\begin{array}{c}\text { Probiotic } 1.5 \mathrm{gm} \\
\text { /liter drinking } \\
\text { water }\end{array}$ & $\begin{array}{c}\text { Antibiotic } \\
\text { 0.3ml/litter } \\
\text { drinking water }\end{array}$ & $\begin{array}{c}\text { Probiotic 1.5gm } \\
\text { and } \\
\text { antibiotic } \\
\text { 0.3ml/litter drinking } \\
\text { water }\end{array}$ \\
\hline $\begin{array}{c}\text { Total serum } \\
\text { cholesterol (mg/dl) } \\
\text { ALT (IU/L) } \\
\text { AST (IU/L) }\end{array}$ & $\begin{array}{c}64.67 \pm 1.21 \mathrm{a} \\
16.29 \pm 0.79 \mathrm{a} \\
215.98 \pm 1.65 \mathrm{a}\end{array}$ & $\begin{array}{c}59.46 \pm 0.40 \mathrm{~b} \\
11.65 \pm 0.54 \mathrm{~b} \\
140.12 \pm 0.97 \mathrm{~b}\end{array}$ & $\begin{array}{c}73.96 \pm 5.22 \mathrm{c} \\
10.45 \pm 1.22 \mathrm{~b} \\
142.28 \pm 0.78 \mathrm{~b}\end{array}$ & $\begin{array}{c}56.12 \pm 5.65 \mathrm{~b} \\
11.76 \pm 0.47 \mathrm{~b} \\
147.65 \pm 0.42 \mathrm{~b}\end{array}$ \\
\hline
\end{tabular}

* Mean \pm S.E. for 10 birds in each group.

Similar letters mean un significant differences $\mathrm{P} \leq 0.05$.

\section{REFERENCES}

Abd-El-Rahman, A.H.; Kamel, H.H.; Walaa, M.A.; Olfat, S.H.; Amir, H.M. (2012). Effect of ${\text { Bactoce } 1{ }^{\circledR} \text { and Revitilyte-plus }}^{\text {tm }}$ as Probiotic food supplements on the growth performance, 
hematological, biochemical parameters and humoral immune response of broiler chickens. World Appl. Sci. J. 18(3), 305-316.

Allouse, B. (1962)."Birds of Iraq". Vlo. I. (in Arabic). Al-Rabita Press, Baghdad.

Amer, M.Y; Khan, S.H. (2012). A comparison between the effects of a probiotic and an antibiotic on the performance of Desi chickens. Veterinary World, 3, 160-165.

Awaad, A.M.; Zouelfeker, S.S. (2001). Project report : Effects of probiotics and combination of E. coli infections in broiler chickens. Cairo University, Faculty of Veterinary Medicine, Department of Poultry Diseases, Giza, Egypt.

Beckett, S.M.; Komar, N.; Doherty, P.F. (2007). Population Estimates for Eurasian Collared-dove in Northeastern Colorado. Wilson J. Ornith. 119(3), 471-475.

David, G.; Eustace, B.; John, C. (2001). Pigeons and Doves: A Guide to Pigeons and Doves of the World. ISBN 0-300-07886-2.

Ergun, A.; Yalcin, S.; Sacakli, P. (2000). The usage of probiotic and zinc bacitracin in broiler rations. Ankara. Univ. Veter. Fakul. Derg. 47, 271-280.

Fuller, R. (1989). Probiotics in man and animal. J. Appl. Bacter.66, 365-378.

Gardiner, G.E.; Casey, G.P.; Garrett, C.P. (2004). Relative ability of orally administered lactobacillus murinus to predominate and persist in the procine gastrointestinal tract. Appl. Envi. Microb. 70, 1895-1906.

Giannini, E.G.; Testa,; Savarino, V. (2005). Liver enzyme alteration: A guide for clinicians. CMAJ. 172(3), 367-79.

Grunenberg, R.; Banik, N.; Kruger, J. (1995). Alanine aminotransferase (ALAT,GPT): a reevaluation of exclusion limits for blood donors. Infusionsther Transfusionsmed. 22(3), 14551.

Hauptmanova, K.; Literak, I.; Bartova, E. (2002). Hematology and leucocytozoonosis of great tits (parus major L.) during winter. Acta Vet. Brno 71, 199-204.

Islam, M.W.; Rahman, M.M.; Kaber, S.M.L.; Kamruzzaman, S.M.; Islam, M.N. (2004). Effects of probiotics supplementation on growth performance and certain haemato-biochemical parameters in broiler chickens. Bangladesh of Veter Medi. 2,39-43.

Kalvathy, R.; Abdullah, N.; Jalaludin, S.; Wong, M.C.V.L.; Ho, Y.W. (2006). Effects of Lactobacillus feed supplementation on cholesterol, fat content and fatty acid composition of the liver, muscle and carcass of broiler chickens. Anim. Res. 55,77-82.

Kamruzzaman, S.M.; Kabir, S.M.L.; Rahman, M.M.; Islam, M.W.; Reza, M.A. (2005). Effects of probiotics and antibiotic supplementation on body weight and haemato-biochemical parameters in briolers. Babgi. J. Vet. Med. 3 (2), 100-104.

Kander, M. (2004). Effect of Bifidobacterium Sp. On the health state of piglets, determined on the bases of haematological and biochemical indices. Elec. J. Polish. Agric. Univ., Available Online http://www.ehpau.media.pl/series/ Volume 7/ Issue 2/ Veterinary/art-07. html.

Mathivanan, R.; Kalaiarasi, K. (2007). Ponchagavya and Andrographis paniculata as alternative to antibiotics growth promoters on haematological, serum biochemical parameters and immune status of broilers. The J. Poult. Sci., 44, 198-204.

Miller, M.J.; Wayland, M.E.; Bortolotti, G.R. (2001). Hemograms for and nutritional condition of migrant bald eagles tested for exposure to lead. J. Wildlife Dis. 37, 481-488.

Modric, S.; Webb, A.I.; Davidson, M. (1999). Effect of respiratory tract disease on pharcokinetics of telmicosin in rats. Lab. Anim. Sci., 49, 248-253.

Mohan, B.; Kadirvel, R.; Natarajan, A.; Bhaskaran, M. (1996). Effect of probiotic supplementation on growth, nitrogen utilization and serum cholesterol in broilers. Br. Poult. Sci. 37, 395-401.

Murwani, R.; Bayuardhi, B. (2007). Broiler serum cholesterol and glutamioxaloacetic transaminase and their relation to antibiotic in feed and medication programs in four broiler producers in semarang region-central Java. Indonesia. Int. J. Poult. Sci. 6, 266-270. 
Nikpiran, H.; Vahdatpour, T.; Babazadeh, D.; Vahdatpour, S. (2013). Effecs of sccharomyces cerevisiae, thepax and their combination on blood enzymes and performance of japanese quails (Coturnix Japonica). The J. Anim. and Plant Sci. 23(2), 369-375 ISSN: 1018-7081.

NRC (National Research Council), (1984). "Nutrient Requirements of Poultry". $8^{\text {th }}$ edn., Revised., Washington D.C., pp.11-15.

Palvak, M.; Vlahovic, K.; Jercic, J.; Dovc, A.; Zupancic, Z. (2005). Age, sexual and seasonal differences of haematological values and antibody status to Chlamydophila sp. In feral and rasing pigeons (Columba livia forma domestica) from an urban environment (Zagreb, Croatia). Eur. J. Wildlife Res. 51, 271-276.

Panda, A.K.; Rama Rao, S.V.; Raju, M.V.L.N.; Sharma, S.R. (2006). Dietary supplementation of lactobacillus sporogenes on performance and serum bioche-mico-lipid profile of broiler chickens. Poult. Sci. 43, 235-240.

Post, J.; Rebel, J.M.J.; Ter Huurne, A.A.H.M. (2003). Physiological effects of elevated plasma corticosterone concentration in broiler chickens. An alternative means by which to assess the physiological effects of stress. Poult. Sci. 82,1313-1318.

Pradhan, R.N.; Sahoo, G.; Mishra, P.K.; Babu, L.K.; Mohapatra, L.M. (1998). Role of probiotics on performance of broiler chicken. Ind. J. Anim. Prod and Manag .14, 80-83.

Steel, R.G.D.; Torrie, J.H. (1980). Principles and procedures of statistics . 2nd edn., Mcgraw-Hill book Co. Inc. New York. USA.

Thongsong, S.K.; Boonrit, T.; Chavanankul, V. (2008). Blood haematologucal-cholesterol profile and antibody titer response of broilers with added probiotic containing both bacteria and yeast or an antibiotic in drinking water.Kalandakanond-Thongsong S. et al., / Thai J. Vet. Med. 38(4), 45-56.

Yeo, J.; Kim, K. (1997). Effect of feeding diets containing an antibiotic, a probiotic, or yucca extract on growth and intestinal urease activity in broiler chicks. Poult. Sci. 76, 381-385. 